\title{
THE EFFECT OF SOCIAL CAPITAL AND HUSBAND-WIFE INTERACTION ON MARITAL QUALITY AMONG FAMILIESIN EARLY YEARS AND MIDDLE YEARS MARRIAGE
}

\author{
Egretta Melistantri Dewi $^{1 *}$, Herien Puspitawati ${ }^{2}$, Diah Krisnatuti $^{3}$ \\ ${ }^{1}$ Program Studi Ilmu Keluarga dan Perkembangan Anak, Sekolah Pascasarjana, \\ Institut Pertanian Bogor, Bogor 16680, Indonesia \\ ${ }^{2,3}$ Departemen Ilmu Keluarga dan Konsumen, Fakultas Ekologi Manusia, Institut \\ Pertanian Bogor, Bogor 16680, Indonesia \\ *Corresponding author: egretta_dewi@yahoo.com
}

\begin{abstract}
This study aims to analyze the effect of social capital and husband-wife interaction on marital quality among families in early years and middle years marriage. The study was using cross sectional design. The selection of research sites was purposively chosen in Bogor City. The location of the study was in Kebon Pedes and Kedung Badak, regions of Tanah Sareal district. Samples of this study were 120 families in early and middle years of marriage with wives as the main participants. Data were collected through interview using questionnaire. The study found that social capital in families with early marriage age in the intermediate category, and in families with middle years of marriage is in the high category. Different test results show only in the dimensions of gender partnerships that families in middle years of marriage were higher than early years families. On variable of husband-wife interaction, half of the families with early marriage years were in the intermediate category and more than half of families with middle years of marriage were in the high category. There wereno significant differences in all dimensions of husband and wife interaction. In the variable quality of marriage, half of families with early years marriage were in the intermediate category, whereas more than half of families with middle years marriage were in high category. There wereno significant differences in all dimensions of marital quality.
\end{abstract}

Keyword: Family, husband-wife interaction, marital quality, social capital

\section{Abstrak}

Penelitian ini bertujuan untuk menganalisis pengaruh modal sosial dan interaksi suami-istri terhadap kualitas perkawinan pada keluarga dengan usia pernikahan awal dan menengah. Penelitian ini menggunakan desain cross sectional. Lokasi penelitian dipilih secara purposive di Kelurahan Kebon Pedes dan Kedung Badak, Kecamatan Tanah Sareal, Kota Bogor. Sampel penelitian adalah 120 unit keluarga dengan usia pernikahan awal dan menengah dengan istri sebagai responden utama. Data dikumpulkan melalui wawancara dengan 
menggunakan kuesioner.Studi tersebut menemukan bahwa Modal sosial pada keluarga dengan usia pernikahan awal berada pada kategori sedang, dan pada keluarga dengan usia pernikahan menengah berada pada kategori tinggi. Hasil uji beda menunjukkan hanya pada dimensi kemitraan gender keluarga dengan usia pernikahan menengah lebih tinggi daripada keluarga dengan usia pernikahan menengah. Pada variabel interaksi suami istri, setengah dari keluarga dengan usia pernikahan awal berada pada kategori sedang dan lebih dari setengah keluarga dengan usia pernikahan menengah berada pada kategori tinggi. Tidak terdapat perbedaan yang signifikan pada semua dimensi interaksi suami istri. Pada variabel kualitas pernikahan, setengah dari keluarga dengan usia pernikahan awal berada pada kategori sedang, sedangkan lebih dari setengah keluarga dengan usia pernikahan menengah berada pada kategori tinggi. Tidak terdapat perbedaan yang signifikan pada semua dimensi kualitas pernikahan.

Kata kunci: Interaksi suami-istri, keluarga, kualitas pernikahan, modal sosial.

\section{Introduction}

Social capital is a network built byshared norms, values, and understandings that facilitate cooperation within or between groups (Cote and Healy, 2001) which can be represented through the relationship between husband and wife. The relationship of married couples in marriage differs from other forms of social relationships because it requires emotional and physical involvement between two individuals. When married, each couple will play a complementary role, giving each other strength and moral support. According to some studies, social capital plays an important role in providing logistical support to maintain a balance between financial adequacy, employment and family functioning, as well as providing emotional support for families which experienceddifficult times to avoid depression, prolonged household conflicts and divorce (Sztaudynger, 2014) and has a role in determining whether a person can maintain his marriage or not (Brinig, 2011).

Based on data taken from the Indonesia Central Bureau of Statistics during the period of 2011-2014 there was an increase in divorce. In 2011, divorce cases occurred at $6.8 \%$, from 2,319,821 cases of marriage and158,119 of them were divorced. In 2012, there were as many as 2,291,265 cases of marriage while the number of divorce were 372,577 cases, so the percentage increased to $16.2 \%$. In 2013, divorce cases decreased to $14.2 \%$ from 2,218,130 cases of marriage and 324,527 divorce cases. The final data of 2014 shows the percentage of divorce increased to $15.3 \%$, with the number of marriages of 2,110,776 and 344,237 divorced. West Java Province ranks third highest after East Java and Central Java, which is as many as 65,848 cases. One of the cities that contribute to the high divorce rate in West Java, is Bogor. Bogor Religious Courts record divorce rate in 2014 were 753 cases, which is a cumulative of six districts. The most contributorcame from Tanah Sareal Sub-district with total cases are 216. While the least is from East Bogor District only 99 cases (BPS Kota Bogor ,2014). 
In addition to social capital, the success or failure of a marriage relationship certainly inseparable from the influence of husband and wife interaction which in some studies referred to as one of the determinants of the quality of marriage (Rosen-Grandon , 2004; Schmitt, 2007 ; Sadeghi , 2012). Marriage interaction is one of the key factors affecting marriage stability, the important role of husband and wife interaction, among others; building the ability of couples to communicate positively (Larso n, et al ., 1998), resolving conflict effectively (Fincham and Rogge , 2010), and efficiently addressing the stressful life situations of marriages (Levenson, et al ., 1995). Supportive communication strengthensthe emotional bond between the two partners and leads to a positive experience in marital relations (Cutrona, 1996). Conformity and incompatibility of married couples referred to overall process and value of husband and wife interactions that dominate their relationships such as trust, solidarity, participation and satisfaction with marriage (Bowen, et al., 2000).

The husband and wife whose take advantage of social capital, resolve the problem by optimizing the interaction of a marriage relationship can achieve the quality of a good marriage. Thus the aspect of development in social capital and husband and wife interaction becomes the top priority in the formation of families with a happy marriage. Various studies of literature studies obtained on social capital, husband and wife interactions and the quality of marriage are interesting to investigate further. Therefore, researchers were interested to know the influence caused by social capital and the interaction of husband and wife on the quality of marriage. This study aims to: (1) identify family characteristics, social capital, the interaction of husband and wife and marriage quality (2) analyze the differences in social capital, the interaction of husband and wife and the quality of marriage in families with early marriage and middle age; (3) analyze the influence social capital and the interaction of husband and wife towards marital quality.

\section{Methods \\ Design, Location and Time Period of Research}

This research usedcross sectional design conducted in Tanah Sareal District, Bogor. Site selection is based on the consideration that Tanah Sareal District has the highest divorce rate in Bogor. Subsequently, the district was chosen purposively based on the number of divorce cases and the existence of middle class families. Most report of divorce cases and middle class families were both located in Kedung Badak and Kebon Pedes villages.

\section{Types and Methods of Data Collection}

The types of data collected in this study include primary data and secondary data. Primary data consist of family characteristics, social capital, husband interaction and marital quality. Secondary data obtained from related institutions with research supporting data and variable literature presented in the form of descriptive. The data collection was done by using self-reporting (self-report) and an interview with a questionnaire tools to measure : (1) family characteristics (age wife, length of wife education, marriage, family members and family income); (2) 
social capital (network, gender partnership, trust and norm) with modified instruments of Trust in Close Relationships Scale (Holmes and Rempel, 1985) for assessing the dimensions of trust, The Network of Relationship Social Provision Version (Furman and Buhrmester, 2009) for dimensions of network, Law No. 1 of 1974 concerning marriage for dimensions of norm and Gender Role Attitude and Marital Role Sharing Norm (Amato and Booth, 1995) for dimensions of gender partnerships; (3) husband and wife interaction with modified instrument from Dyadic Adjustment Scale (Spanier and Lewis , 1976) ; (4) the quality of a marriage with a modified instrument of Enrich (Enriching and Nurturing Relationship Issues, Communication and Happiness Inventory) (Fowers, et al., 1993) for dimensions of marriage happiness, Marital Satisfaction Scale (MSS) (Canel, 2013) for dimensions of marital satisfaction and Marital Adjustment Test (MAT) (Locke and Wallace, 1959) for dimensions of adjustment .

\section{Processing and analysis of data}

The data has been collected and processed through entry, editing, coding, cleaning, scoring, and data analysis. Processing and data analysis was done by using Microsoft Excel program and Statistical Package for Social Science (SPSS). Primary data were analyzed descriptively including average, standard deviation, minimum and maximum values. Inferential data t-test which is used to distinguish between research variables between groups of respondents with early marriage age and middle age of marriage, and multiple linear regression test to determine the effect of social capital and husband and wife interaction on the quality of marriage. Quality of capital data social, husband and wife interactions and marriage quality is controlled by conducting reliability test and validity test. The social capital questionnaire consists of 28 questions and its Cronbach's alpha value 0,915 . The wedding interaction questionnaire consists of 23 questions and has Cronbach's alpha value 0.880 . Wedding quality questionnaire consists of 25 items and values Cronbach's alpha of 0.953. Index scores achieved are categorized based on class ranges. Three categories are used, namely low, medium, high. Cut off which will be used to categorize social capital variables, husband and wife interactions and marriage quality, namely : a. Low: 0-50 b. Moderate: 50 .0 1-75 c. High: 75 .0 1-100 .

\section{Findings}

\section{Family Characteristics}

This study involved 120 middle class families consisting of 60 families with an early marriage age (0-5 years) and 60 families with middle age marriage (6-15 years). The selected respondents were wives with an average age of 32.37 years. Minimum age of respondents is 21 years, while the maximum age is 45 years.

The results show that the majority of respondents are not working and prefer to be housewives $(74,17 \%)$. Respondents are high school graduates with 12-year study period, which amounted to 76,7 percent. The results do not show the duration of education less than 6 years.

Based on the data, it is known that 90 percent of respondents hada total family member less than 4 people and belong to a small family group. Medium family 
groups 5-7 people only 10 percent of all respondents. The results of the study found no respondents had more than 8 family members or larger family groups.

Family income is measured by calculating all family members' income working in the formal and non-formal sectors for one month. Categorization based on family income poverty line indicator of Bogor in 2015, amounting to Rp.392.405,-. Overall, there were no respondents that lived below the poverty line.

\section{Social Capital}

Social capital is a potential relationship patterns among individuals within a family of network dimension, gender partnership, trust and norms which can facilitate mutual coordination and cooperation among its members. The index scores achieved are categorized by class ranges: a. Low $=0-50 ; \mathrm{b}$. Moderate $=$ 50.01-75; c. High $=75.01-100$. The results showed that the average network index score on early years marriage category was 75.83 and in high category while on the group middle years of marriage category was 74.24 and in low category. Ttest results showed that there was no significant difference in the dimensions of network between the two groups of respondents. The average score of gender partnership index for respondents in their early yearsof marriage was low, i.e. at 71.67 but high for respondents on middle years of marriage, i.e. at 76.39. However, t-test results showed that there was significant differencein the dimension of gender partnership. Gender partnerships in middle years of marriage were higher than in early years. The average score of trustonearly years of marriage was 75.62 percent and in high category, while the average value of truston middle years of marriage was 74.38 percent and in low category. T-test results showed no significant difference between early years marriage category with middle years marriage category regarding dimension of trust. The average score of the norm dimension on early years of marriage group was 76.67 and the category was high while the middle years group was 80.11 , which was also in high category. T-test results did not show any significant difference between middle years of marriage category and early years of marriage in the norm of dimension (Table 1).

Table 1.Mean values, standard deviations and t-test coefficient of social capital.

\begin{tabular}{|c|c|c|c|c|}
\hline \multirow[t]{2}{*}{ Dimensions of Social Capital } & $\begin{array}{l}\text { Early Years of Marriage } \\
(n=60)\end{array}$ & $\begin{array}{l}\text { Middle Years of Marriage } \\
(\mathrm{n}=60)\end{array}$ & $\begin{array}{c}\text { Total S c ore } \\
(n=120)\end{array}$ & \multirow[t]{2}{*}{$p-v a l u e$} \\
\hline & $\mathrm{R}$ a t a a $\mathrm{n} \pm \mathrm{S} \mathrm{D}$ & $\mathrm{R}$ a t a a $\mathrm{n} \pm \mathrm{S} \mathrm{D}$ & $\mathrm{R}$ a t a a $\mathrm{n} \pm \mathrm{S} \mathrm{D}$ & \\
\hline $\begin{array}{lllllll} & \mathrm{e} & \mathrm{t} & \mathrm{w} & \mathrm{o} & \mathrm{r} & \mathrm{k}\end{array}$ & $75.83 \pm 12.58$ & $74.24 \pm 14.92$ & $75.03 \pm 13.766$ & 0.527 \\
\hline Gender partnership & $71.67 \pm 12.89$ & $76.39 \pm 13.52$ & $74.03 \pm 13.361$ & $0.053 *$ \\
\hline $\mathrm{u}$ & $75.62 \pm 13.78$ & $74.38 \pm 14.91$ & $75.00 \pm 14.310$ & 0.639 \\
\hline $\mathrm{o} \quad \mathrm{r}$ & $76.67 \pm 14.29$ & $80.11 \pm 13.75$ & $78.39 \pm 14.069$ & 181 \\
\hline Tot a 1 S c o r e & $75.02+10.55$ & $75.79+11.95$ & $75.41+11.23$ & 0.708 \\
\hline
\end{tabular}

\section{Husband and wife interaction}

Husband and wife interaction is a reciprocal relationship between husband and wife showing a mutual influenceprocess. The husband and wife intraction 
variables are formed based on the dimensions of consensus, cohesion and affectionate expression. Index scores achieved are categorized based on class ranges: a. Low $=0-50 ;$ b. Moderate $=50.0 ; 1-75 ;$ c. High $=75.0 ; 1-100$. The results of the analyses show that respondents from both categories of marriage duration have high level of consensus. The average index score of consensus for each category amounted to 75.93 on early years of marriage category and 79.75 onmiddle years of marriage category. Both groups of respondents have had high categorized consensus dimension scores. T-test of the consensus dimension shows no significant difference between early years with middle years of marriage. The average cohesion index score for each category was 78.77 on the early years of marriage and 81.30 on the middle years of marriage category. Both respondents groups have high categorized cohesion dimension scores. T-test results of cohesion do not show any significant difference. Mean of value score of affectionate expression showed that both groups of respondents have low categorized affectionate expressionwith only 63.89 for early years of marriage group and 62.22 for middle years of marriage. T-test results of norm dimension showed no significant difference between early years of marriage and middle years of marriage (Table 2).

Table 2. Mean value, standard deviation and t-test coefficient of husband-wife interaction.

\begin{tabular}{|c|c|c|c|c|}
\hline \multirow[t]{2}{*}{ Dimensions of Husband-Wife Interaction } & $\begin{array}{l}\text { Early Years of Marriage } \\
(\mathrm{n}=60)\end{array}$ & $\begin{array}{l}\text { Middle Years of Marriage } \\
(\mathrm{n}=60)\end{array}$ & $\begin{array}{c}\text { Tot a l S c o re } \\
(n=120)\end{array}$ & \multirow[t]{2}{*}{$p$-value } \\
\hline & $\mathrm{R}$ a t a a $\mathrm{n} \pm \mathrm{S} \mathrm{D}$ & $\mathrm{R}$ a t a a $\mathrm{n} \pm \mathrm{S} \mathrm{D}$ & $\mathrm{R}$ a t a a $n \pm S \mathrm{D}$ & \\
\hline $\mathrm{C}$ o n s e n s u s & $75.93+15.21$ & $79.75 \pm 12.96$ & $77.84 \pm 14.20$ & 141 \\
\hline \multirow{2}{*}{$\begin{array}{l}\mathrm{C} \text { o } \mathrm{h} \text { e } \mathrm{s} \quad \mathrm{i} \quad \mathrm{o} \quad \mathrm{n} \\
\text { Affectionate Expression }\end{array}$} & $78.77+9.90$ & $81.30 \pm 11.46$ & $80.03 \pm 10.740$ & 0.198 \\
\hline & $63.89+19.03$ & $62.22+22.42$ & $63.06+20.723$ & 0.661 \\
\hline Tot a 1 S c o r e & $74.42 \pm 10.56$ & $76.55 \pm 11.10$ & $75.48 \pm 10.84$ & 0.285 \\
\hline
\end{tabular}

\section{Marital Quality}

Marital quality is a measure based on the dimensions of marital happiness, marital satisfaction and marital adjustment between husband and wife in living a household. The index scores achieved are categorized by class ranges: a. Low $=0$ 50 ; b. Moderate $=50.01-75 ;$ c. High $=75.01-100$. On dimensions of marital satisfaction the average value obtained by the early years of marriage category was 79.95 while for the middle years of marriage category was 81.97. The results showedboth groups have high categorized satisfaction dimension score and t-test results did not show any significant differences. The average value of marital happiness obtained by early years of marriage category was 76.18 while for the middle years of marriage category was 78.61. These results indicated both groups of respondents have high categorized happiness dimension score. The results of different tests did not show any significant differences between the two categories/groups. The average value of marital adjustments obtained by respondents in their early years of marriage was 76.18 while for respondents in their middle years of marriage was 78.61. It can be seen from these results that the level of marital adjustment held by respondents in middle years of marriage category is higher than the respondents in early years of marriage category. 
Although, t-test results did not show any significant differences between the two categories (Table 3).

Table 3. Mean values, standard deviations and t-test coefficients of marital quality

\begin{tabular}{|c|c|c|c|c|}
\hline \multirow[t]{2}{*}{ Dimensions of Marital Quality } & $\begin{array}{l}\text { Early Years of Marriage } \\
\qquad(\mathrm{n}=60)\end{array}$ & $\begin{array}{l}\text { Middle Years of Marriage } \\
\qquad(\mathrm{n}=60)\end{array}$ & $\begin{array}{l}\begin{array}{l}0 \quad \mathrm{t} \quad \mathrm{a} \quad \mathrm{l} \\
(\mathrm{n}=120)\end{array}\end{array}$ & \multirow[t]{2}{*}{$p$-value } \\
\hline & $\mathrm{R}$ a t a a $\mathrm{n} \pm \mathrm{S} \mathrm{D}$ & $\mathrm{R}$ a t a a $\mathrm{n} \pm \mathrm{S} \mathrm{D}$ & $\mathrm{R}$ a t a a $\mathrm{n} \pm \mathrm{S} \mathrm{D}$ & \\
\hline Marital happiness & $79.95+13.17$ & $81.97+13.11$ & $80.96+13.13$ & 0.141 \\
\hline Marital satisfaction & $76.18+13.49$ & $78.61+12.92$ & $77.40+13.21$ & 0.198 \\
\hline Marital adjustment & $74.07+13.28$ & $74.72+13.35$ & $74.40+13.27$ & $\begin{array}{lll}6 & 6 & 1\end{array}$ \\
\hline $\mathrm{N}$ i l a i to t a l & $77.33 \pm 12.65$ & $79.16 \pm 12.01$ & $78.24 \pm 12.31$ & 0.420 \\
\hline
\end{tabular}

\section{Factors Affecting Marital Quality}

Table 4 shows that the wife's employment, social capital and the interaction of the husband and wife hadan influence on the quality of marriage. The factor that has the greatest influence on the quality of marriage is social capital. The variables in this study affect the quality of marriage at 65.7 percent.

Wife's employement has a very significant influence on marital quality. Marital quality score on working wife was lower at 5,304 points compared with stay at home-wives. Family social capital and husband-wife interactions hada very significant and positive influence on marital quality. Each increase in social capital index score of one unit will increase the index score of marital quality at 0.577 and each increase of husband-wife interaction score as much as one unit will increase the score of marital quality index at 0.387 . This shows that the better of the family's social capital and couple interaction the better themarital quality will be.

Table 4 .The Influence of Family Characteristics, Environmental Characteristics, Social Capital and Husband Wife Interaction Against Quality of Marriage

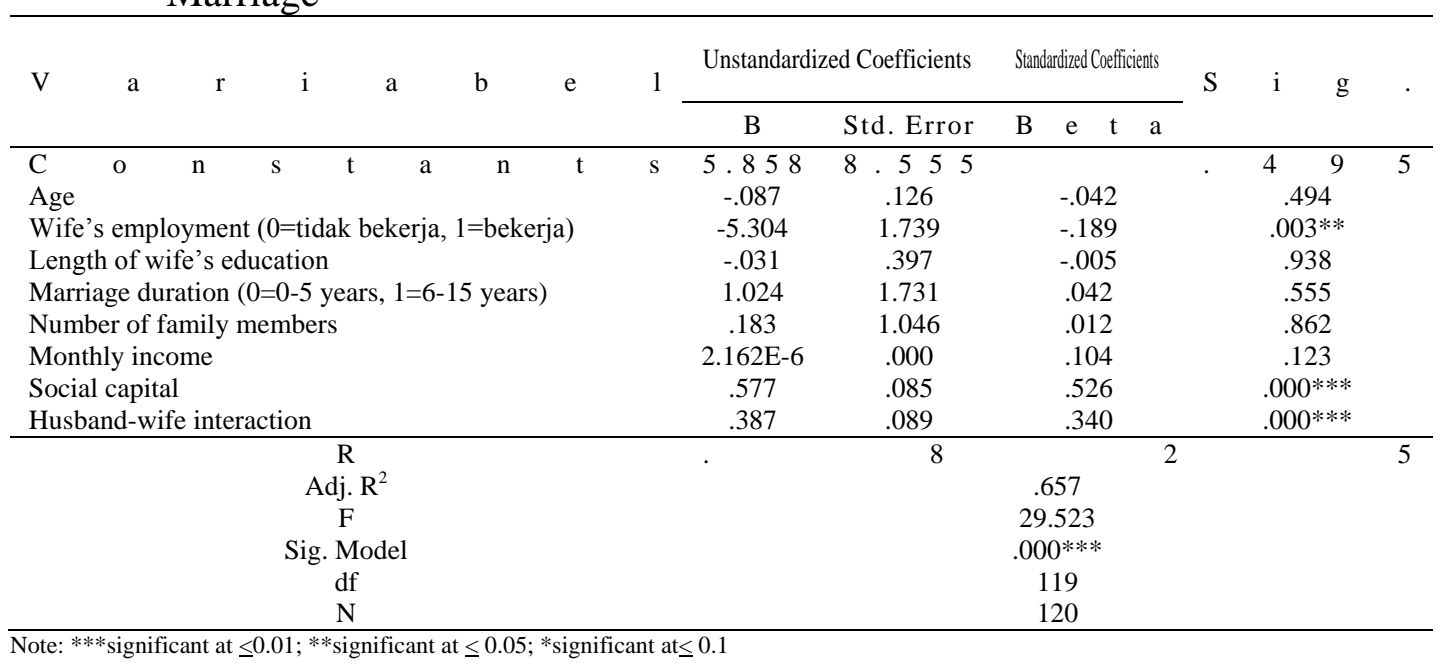

\section{Discussion}


The results showed that social capital and husband-wife interaction have positive effect on marital quality. This finding supported by several studies which suggest that social capital in the form of trust, reciprocal relationships and cooperation in carrying out domestic responsibilities can affect the quality and satisfaction of marriage (Brinig, 2011; Scheeren, 2014; Kabakova, 2012). The interaction of couple contribute positively to the quality of marriage, in line with the results of research Sadeghi (2014) which concluded that the better the interaction of the couple, the level of satisfaction of marriage will be higher.

Wife's employment also gives a very significant effect on the quality of marriage. The results show that working wives have low marital qualities; these findings are in line with Cooke et al. (2013) that the effect of women working on marriage degradation is very significant, especially in areas that embrace traditional gender roles. Some studies conclude that the quality of marriage is related to the length of marriage (Carrere, 2000, Gottman, 2002; Kreider and Ellis, 2011; Kulu, 2014), but in this study there is no relationship or influence of factors long married to the quality of marriage.

The test results showed that there was no significant difference of social capital in the group of respondents of early years of marriage (0-5 years) with middle years of marriage (6-15 years). However, gender partnerships dimension had a significant difference.The gender partnership scores for middle years of marriage group of respondents were higher than those inthe early years. Couples with a marriage durationless than 5 years tend to have difficulty in balancing and negotiating roles and responsibilities in marriage (Hall, 2011).

In addition to social capital, husband-wife interactions and marital quality also did not show significant differences in both groups of respondents. The findings in this study are inconsistent with the previous findings of reference (Carrere, 2000; Gottman, 2002; Kreider and Ellis, 2011; Kulu, 2014) which concluded that the marital quality is associated with long-term marriage, but in this study there were no relationships and influences of long-term marriage to the marital quality.

The factor that is assumed to be the determinant is the social class characteristic of the whole respondents families, based on income criteria, belong to middle-class families with average per capita income above the poverty line determined by Bogor city government. One of the most important aspects inachieving welfare is the ease of obtaining and utilizing social capital and in this case middle-class families fulfill that aspect (Nasution, et al., 2014; Bowman, 2016). Middle class families generally have a good interaction due to the low emotional pressure caused by economic hardship, so it tends to contribute well in achieving the desired marital quality (Gudmunson, 2017).

\section{Conclusion and Recommendation}

\section{Conclusion}

Social capital in families with early years of marriage is in the high category and in families with middle years of marriage is in thelow category. This study found no differences between social capital in families with early years of marriage and middle years of marriage. However, there were significant 
differences in the dimensions of gender partnerships that show the achievement of gender partnerships in the middle years of marriage group of respondents is higher than the respondents group in early years of marriage. Husband-wife interaction and marital quality did not show differences between families with early and middle years of marriage. In the husband-wife interaction, half of the families with early years of marriage were in the low category and more than half of families with middle years of marriage were in the high category. There was no significant difference in all dimensions of husband and wife interaction. In the variable of marital quality, half of families with early years of marriage were in the low category, while more than half of families with middle years of marriage were in the high category. Overall, there is no significant difference in marital quality.

In this study it is known that the factors that have a very positive significant effect on the quality of marriage were social capital and husband-wife interaction, while wife's employment has an negative effect on marital quality. It can be concluded that the higher social capital and husband-wife interaction will improve the quality of marriage.

\section{Recommendation}

Based on the results of the research, working wives tend to have low levels of marriage quality, it can be suggested that working wives can balance their role in public and domestic aspects. Therefore, it is important for husbands to help such as providing a household assistant facility that can take over domestic work and childcare while the wife is at work because of the pressure her wife has on her effort to balance work and family can reduce the interaction of husband and wife and increase the odds decreased quality of marriage.

It is also important to note that as more and more married women join the workforce, it is good for employers to help by setting family-friendly policies, such as reducing overtime, providing daycare and maternal rooms. Participating husbands in helping wives balance their roles is seen as a form of gender partnership and as one of the components of social capital and positive husbandwife interactions based on research results have a significant effect on the quality of marriage.

The limitation of this study is that the research was only selected wife as the main respondent, it is expected that further research can be implemented by considering the perception of the husband in assessing the quality of marriage. In addition, it is expected that further research will be made to explore the components of social capital and husband-wife interactions and link them with families and marriages.

\section{References}

Amato, P. R., Booth, A. (1995). Changes in gender role attitudes and perceived maritalquality. American Sociological Review, 60, 58-66. 
Bowen, G. L., Martin, J. M., Mancini, J. A., Nelson, P. J. (2000). Community Capacity:Antecedents and Consequences. Journal of Community Practice, Vol. 8(2) 2000.

Bowman, S. W. (2016). Who and What You Know: Social and Human Capital in BlackMiddle-Class Economic Decision-Making. Race and Social Problems (2016) 8:93-102.doi:10.1007/s12552-016-9169-6

Brinig, M. F. (2011). Belonging and Trust: Divorce and Social Capital. Faculty Scholarship. Notre Dame Law School.

Canel, A. N. (2013). The Development Of The MaritalSatisfaction Scale (MSS).Educational Sciences: Theory \& Practice 13(1)Winter97-117. Educational Consultancy and Research Center. Marmara University.

Carrere, S., Buehlman, K. T., Gottman, J. M., Coan, J. A.,Ruckstuhl, L. (2000). Predicting Marital Stability and Divorce in Newlywed Couples.Journal of Family Psychology, 14(1), 42-58.

Cooke, L.P., Erola, J., Evertsson, M., Gähler, M., Härkönen, J., Hewitt, B., Jalovaara, M., Kan, M.-Y., Lyngstad, T.H., Mencarini, L., Mignot, J.-F., Mortelmans, D., Poortman, A.-R., Schmitt, C., and Trappe, H. (2013). Labor and Love: Wives' Employment and Divorce Risk in its SocioPolitical Context. Social Politics: International Studies in Gender, State \& Society 20(4): 482-509.

Cote, S dan Healy, T. (2001). The Well-Being of Nations. The Role of Human And Social Capital. Paris: Organizationfor Economic Cooperation and Development.

Cutrona, C. E. (1996).Social Support as a Determinant of Marital Quality. Handbook of Social Support and the Family pp 173-194.

Fincham, F. D., Rogge, R. (2010). Understanding Relationship Quality: TheoreticalChallenges and New Tools for Assessment.Journal of Family Theory \& Review 2(December 2010): 227-242 227.doi:10.1111/j.17562589.2010.00059.x

Fowers, B. J.,Olson, D. H. (1993). ENRICH Marital Satisfaction Scale: A Brief Research and Clinical Tool. Journal of Family Psychology 1993, Vol. 7, No. 2, 176-185.

Furman, W., Buhrmester, D. (2009).The Network of Relationships Inventory: Behavioral SystemsVersion. International Journal of Behavioral Development. $2009 \quad$ September $\quad 1$; $33(5)$ : $\quad 470$ 478.doi:10.1177/0165025409342634.

Gottman, J. (2002). The Seven Principles for Making Marriage Work. Three Rivers Press: Crown Publishing Group: New York.

Gudmunson, C. G., Beutler, I. F., Israelsen.C. L., McCoy, J. K. E., Hill, J. (2017). Linking Financial Strain to Marital Instability: Examining the Roles of Emotional Distress and Marital Interaction. Journal of Family Economic Issues(2017) 28:357-376.doi:10.1007/s10834-007-9074-7

Hall, S. S.,Adams, R. A. (2011). Newlyweds' unexpected adjustments tomarriage. Family and Consumer Sciences Research Journal, 39, 375-387.

Holmes, J.G., Rempel, J.K. (1985). Trust in close relationships. In C. Hendrick (Ed.), Close relationships:Review of personality and social psychology (Vol. 10, pp. 187-220). Newbury Park, CA: Sage Publications. 
Joseph, S., Inbanathan, A. (2016).A Sociological Review ofMarital Quality amongWorking Couples inBangalore City. The Institute for Social and EconomicChange. Bangalore

Kulu, H. (2014). Marriage Duration and Divorce: The Seven-Year Itchor a Lifelong Itch?Population Association of America 2014 Demography (2014). 51:881-893 doi.10.1007/s13524-013-0278-1

Kreider, R. M., Ellis, R. (2011). Number, Timing, and Duration ofMarriages and Divorces.Household Economic Studies.

Larson, J. H., Anderson, S. M., Holman, T. B., Niemann, B. K.(1998). A longitudinal study of the effects of premarital communication, relationship stability, and self-esteem on sexual satisfaction in the first year of marriage.Journal of Sex \& Marital Therapy 1998 Jul-Sep;24(3):193-206. DOI: $10.1080 / 00926239808404933$

Ledermann, T., Bodenmann, G., Rudaz, M., Bradbury, T. N.(2010). Stress, Communication, and Marital Quality in Couples. Family Relations 59 (April 2010): 195 - 206 195. doi:10.1111/j.1741-3729.2010.00595.x

Levenson, R. W., Carstensen, L. L., Gottman, J. M. (1995). Emotional Behavior in Long-Term Marriage. Psychology and Aging1995. Vol. 10. No. I. 140149.

Locke, H.J. dan Wallace, K. M. (1959). Short Marital Adjustment And Prediction Tests: Their Reliability And Validity. Marriage and Family Living, 21, 251-255.

Nasution, A., Rustiadi E., Juanda B; HadiS. (2015).Two-Way Causality between Social Capital and Poverty in RuralIndonesia.Asian Social Science; Vol. 11, No. 13; 2015

Rosen-Grandon, J. R., Myers,J.E., Hattie, J. A. (2004). The relationship between marital characteristics, marital interaction processes, and marital satisfaction. Journal of Counseling and Development : JCD; Winter 2004; 82, 1; ProQuestpg. 58

SadeghiMS, MazaheriMA, Motabi DF, Zahedi K. (2012). Marital interaction in iranian couples: examining the role of culture. Journal of Comparative Family Studies 43.2 (2012): 281-XVII.Shahid Beheshti University (GC): Iran.

Schmitt, M. (2007). Marital interaction in middle and old age:a predictor of marital satisfaction?Int'l. J. Aging and Human Development,Vol. 65(4) 283-300, 2007.Baywood Publishing: New York.

Sztaudynger, J.J. (2014). Family Social Capital, Marriage and Fertility. Folia Oeconomica Stetinensia.doi: 10.1515/foli-2015-0009.

Spanier, G. B. (1976). Measuring Dyadic Adjustment: New scales for Assessing The Quality of Marriage and Similar Dyads.Journal of Marriage and Family, 38(1), 15- 28. 